\title{
Structural dynamic analysis of the epicentral zone of the Ilin-Tas earthquake (Feb 14, 2013, $\left.M_{s}=6.9\right)$
}

\author{
L. P. Imaeva • B. M. Koz'min • V. S. Imaev • \\ K. G. Mackey
}

Received: 27 March 2014 / Accepted: 23 October 2014 / Published online: 11 December 2014

(C) The Author(s) 2014. This article is published with open access at Springerlink.com

\begin{abstract}
The paper presents the results of analysis of tectonics, modern relief morphology, active faults, and types of Cenozoic deformations in the epicentral area of the Ilin-Tas $\left(M_{s}=6.9\right)$ earthquake, one of the strongest events registered at the boundary of the Eurasian and North American lithospheric plates in northeast Russia. Geological, tectonic, and geophysical characteristics of the Yana-Indigirka segment of the Chersky seismotectonic zone are studied. The methods of investigation were elaborated at the Institute of the Earth's Physics, RAS (Moscow), and were adapted to conducting seismotectonic work on the territory of northeast Russia. The results of instrumental observations are summarized, and manifestations of strong seismic events are discussed. Description is given of the structural-tectonic setting in which the Andrei-Tas
\end{abstract}

L. P. Imaeva $\cdot$ V. S. Imaev $(\bowtie)$

Institute of the Earth's Crust, Siberian Division,

Russian Academy of Science, 128 Lermontova,

Irkutsk, Russia 664033

e-mail: imaev@crust.irk.ru

B. M. Koz'min

Institute of Diamonds and Precious Metals Geology, Siberian Division, Russian Academy of Sciences, 39 Lenin Prospekt,

Yakutsk, Sakha Republic (Yakutia), Russia 677891

K. G. Mackey

Department of Geological Sciences, Michigan State

University, East Lansing, MI 48824, USA

V. S. Imaev

Technical Institute (Branch) of the North Eastern Federal

University, 16 Kravchenko, Neruyngri, Russia 678960 seismic maximum developed. It originated under the effect of the Kolyma-Omolon terrane (indentor) which "intruded" into the Chersky seismotectonic zone on the side of the North American plate, thus leading to the formation of major seismoactive structures in the frontal Ilin-Tas folded zone. The indentor moved in NE-SW direction, which is consistent with the orientation of the major axis of isoseism ellipses (azimuth $50-85^{\circ}$ ) constructed from observation of macroseismic effects of the Uyandina $\left(\mathrm{M}_{\mathrm{s}}=5.6\right)$, Andrei-Tas $\left(\mathrm{M}_{\mathrm{s}}=6.1\right)$, and Ilin-Tas $\left(\mathrm{M}_{\mathrm{s}}=6.9\right)$ earthquakes.

Keywords Ilin-Tas (Abyi) earthquake · Yana-Indigirka segment $\cdot$ Chersky seismotectonic zone $\cdot$ KolymaOmolon indentor - Andrei-Tas block · Focal mechanism . Isoseisms · Active faults · Dynamics of seismotectonic processes

\section{Introduction}

The beginning of the twenty-first century was marked by growing seismic activity in northeastern Yakutia. The Feb 14, 2013, Ilin-Tas (Abyi) earthquake is among the strongest seismic events registered during the period of operation of the regional seismic network in northeast Russia. The epicentral zone of the earthquake was located within the seismic maximum of the Andrei-Tas block (northeastern side of the Yana-Indigirka segment of the Chersky seismotectonic zone) where, along with numerous weak shakes, strong quakes $\left(\mathrm{M}_{\mathrm{s}}=5.2-6.1\right)$ have been detected earlier. 
Summary of the results of instrumental observations obtained by workers of the Geophysical Survey of the Siberian Branch, Russian Academy of Sciences, and the Michigan State University (USA) as well as joint studies of strong earthquake manifestations and interpretation of the available geological-structural (Parfenov et al. 2001; Imaev et al. 1990, 2000) and morphotectonic data permitted making a structural dynamic analysis of the epicentral zone of the Ilin-Tas earthquake and refining the dynamics of major seismotectonic processes occurring on the northeastern side of the Yana-Indigirka segment of the Chersky seismotectonic zone.

Methodical basics of seismotectonic investigations were elaborated at the Institute of the Earth's Physics, RAS (Ulomov 1995; Shebalin et al. 1995; Ulomov and Shumilina 1998), and were further adapted in the course of seismotectonic work on the territory of northeast Russia (Imaeva et al. 2009, 2010, 2011, 2012).

The aims of the investigations were the following:

- analysis of published structural-tectonic, geological-geophysical, and seismological data and compilation of additional maps characterizing general morphotectonics of the region

- revealing seismotectonic reactivation of the Late Mesozoic tectonic structure of the region and determining its effect on modern topography and the type of Cenozoic deformation processes

- refining the kinematics of motions on the northeastern side of the Yana-Indigirka segment and working out a regional structural dynamic model of major seismogenerating zones

\section{Structural-tectonic setting}

The Ilin-Tas earthquake was located within the northeastern segment of the Verkhoyansk-Kolyma fold system. In the periods before neotectonic time, the tectonic history of the system formation was controlled by active tectonic processes taking place there in the Late Jurassic-Early Cretaceous, when structures of the passive continental margin, which developed in the eastern framing of the Siberian platform, collided with the Alazeya island arc (Gusev 1979; Parfenov 1984). Destruction of the Earth's crust on the territory of Mesozoides has been lately thought to be related to the collision of the North Asian craton and the Kolyma-
Omolon block (terrane), which was earlier shown as the Kolyma-Omolon median massif on all tectonic maps (Parfenov et al. 2001). The collision produced terranes of different geodynamic nature and caused complex folding of thick terrigenous rocks of Cambrian, Permian, Triassic, and Jurassic age.

The area of the Ilin-Tas earthquake manifestation is on the northeastern side of the Yana-Indigirka segment of the Chersky seismotectonic zone (Fig. 1). It included in pre-neotectonic period frontal contact zones of the Kolyma-Omolon block (Indigirka-Zyryanka basin) and the Ilin-Tas anticlinorium (Imaev et al. 1990, 2000; Imaeva et al. 2010, 2011). The Ilin-Tas anticlinorium is characterized by intense folding of the Upper Jurassic cleaved schists, which are deformed into packets of isoclinal folds with the axial surfaces inclined to the south and southwest (Fig. 2). The Indigirka-Zyryanka basin extends over a distance of $450 \mathrm{~km}$ along the northeastern foothills of the Moma Range and has an asymmetric structure. The most subsided southwestern edge of the basin with the total thickness of $2500 \mathrm{~m}$ is complicated by imbricate thrusts and reverse faults with the involvement of the Upper Jurassic and Cretaceous rocks of the Moma Range piedmont (Gusev 1979; Gaiduk and Prokopiev 1999; Prokopiev and Deikunenko 2001).

The collision of Indigirka-Zyryanka basin and Ilin-Tas anticlinorium in the neotectonic time contributed to their horizontal warping. As a result, the Ilin-Tas folded zone, which is orographically expressed as the Moma Range, was formed from Indigirka River to Kolyma River.

\section{Morphotectonics}

The Yana-Indigirka segment of the Chersky seismotectonic zone is represented by structures on the northeastern side of the frontal zone of interaction of the Eurasian and North American plates (Fig. 1). Their zone of collision with a different deep structure to adjacent deformation zones includes a collage of terranes that originated under certain geodynamic conditions (Parfenov et al. 2001) and is expressed, in modern topography, as a complex of fault-block structures.

The area of manifestations of the Ilin-Tas earthquake is confined to the northwestern termination of a neotectonic structure known as the Andrei-Tas block, which is separated from the Moma Range by northeastern right lateral strike slip (Fig. 1). The Ilin-Tas block is 


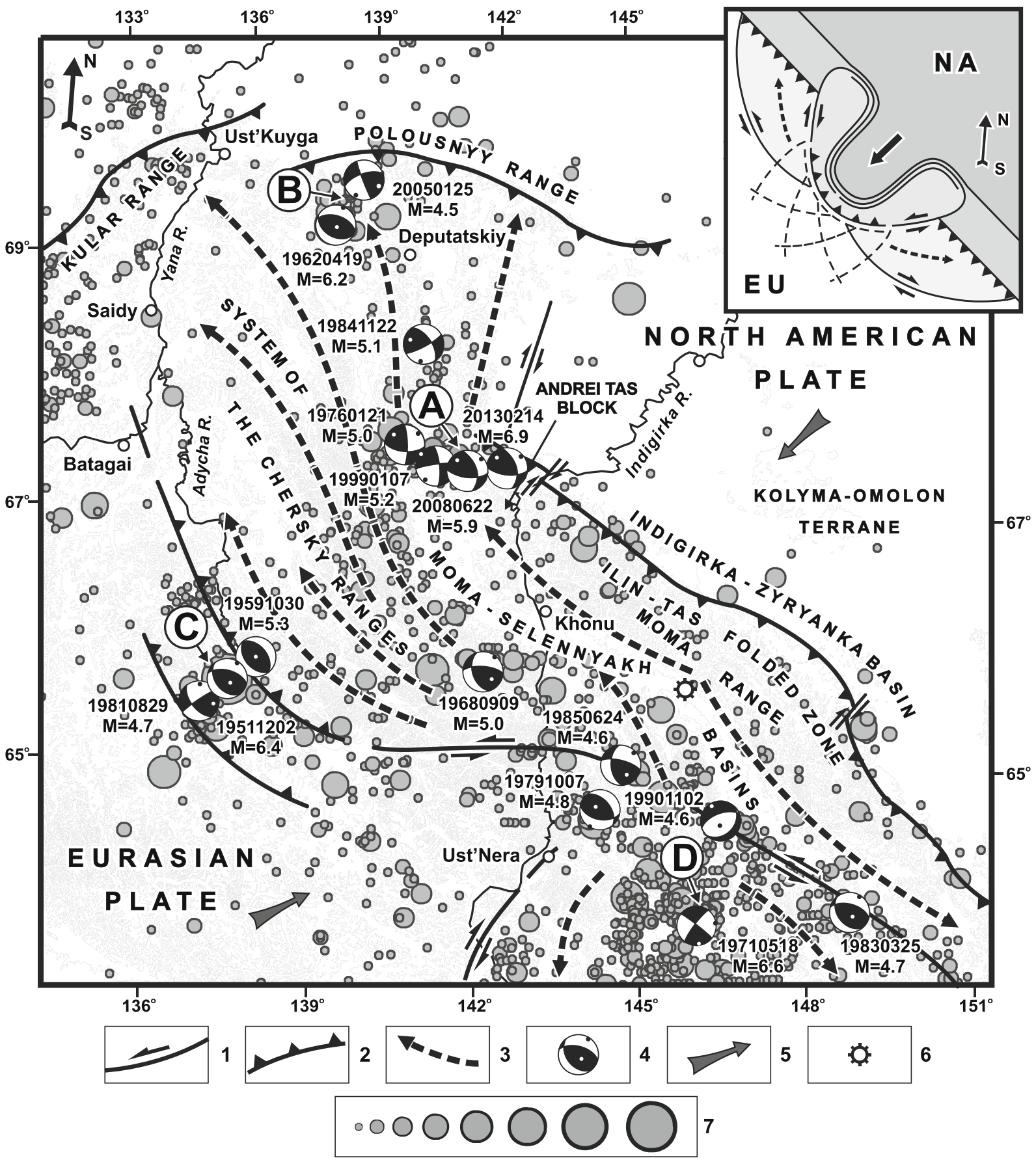

Fig. 1 Modern dynamics and spatial distribution of epicenters in the Yana-Indigirka segment of the Chersky seismotectonic zone (Arctic-Asian seismic belt) [after Imaeva et al. 2010], supplemented. 1-2, Active faults: 1 strike-slip fault, 2 thrust and reverse faults; 3 , sense of block motion; 4 , focal mechanism stereograms, with the date and magnitude of earthquake; 5 , sense of motion of

adjoined on the east by the Indigirka-Zyryanka basin filled with Cretaceous and Cenozoic deposits grading lithospheric plates; 6 , Balagan-Tas volcano; 7, magnitude of earthquakes (mb), respectively: $\leq 3.0,3.5,4.0,5.5,5.0,5.5,6.0 \geq 6.5$. Seismicity maximums: $A$, Andrei-Tas; $B$, Polousny; $C$, Adycha; $D$, Upper Nera. Outset shows simplified model of the indenter [after Moores and Twiss (1995)]

further northeast into the sediments of the YanaIndigirka lowland. 
A. Indigirka - Zyryanka basin
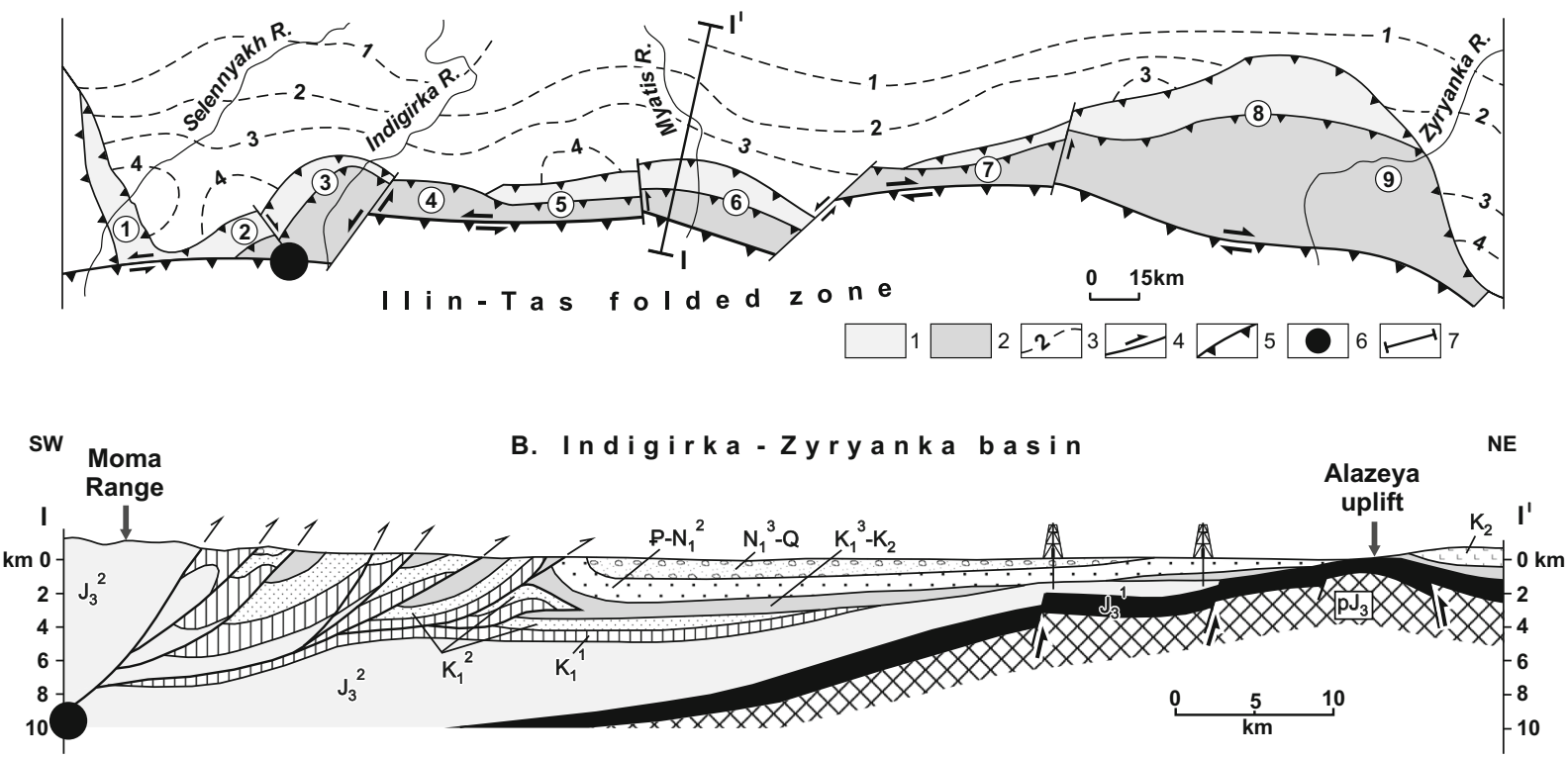

Fig. 2 Location of the Ilin-Tas earthquake on the tectonic map (a) and in the structural geologic section (b) [after Gaiduk and Prokopiev (1999)], supplemented. 1, Frontal belt; 2, rear belt; 3, isolines of the roof of the pre-Ilin-Tas basin from drilling and geophysical data; 4-5, active faults: 4 strike-slip fault, 5 thrust

The morphology of the Andrei-Tas block, its structural-tectonic setting, and the presence of thrusts bounding it along the perimeter suggest the structure is a klippe. The block has a rectangular isometric structure and is involved in intense (up to $2500 \mathrm{~m}$ ) uplifting with the formation of different-sized disjunctive dislocations of various kinematics. The block is rimmed along strike by a series of thrusts and reverse faults well seen on different-scale space images. Its central part is dominated by strike-slip faults branching out, at their ends, into a fan-like series of thrusts and reverse faults.

Space images available at the site "Geoportal Roskosmos" (http://www.geoportal.ntsomz.ru) show a series of seismotectonic dislocations in the innermost isoseism zones of the Andrei-Tas and Ilin-Tas earthquakes, which likely resulted from these events (Fig. 3 ). In the northwestern area of the frontal part of the Andrei-Tas block, in the epicentral zone of the AndreiTas earthquake, a light strip is traced over a distance of $7-8 \mathrm{~km}$, which is deciphered as rejuvenation of an NStrending arched fault. It is shown on the space image by white arrows (Fig. 3(A)). The strike and morphology of the fault suggest strike slip and upthrow motions along its plane. In the zone adjacent to the straightened segment of the Selennyakh River, the watershed part of the and reverse faults; 6 , epicenter and hypocenter of the Ilin-Tas earthquake; 7 , the profile line $B$. Numbers designate segment: 1 , Selennyakh; 2, Tomtor; 3, Indigirka; 4, Kuranakh; 5, Kyllakh; 6, Myatis; 7, Burgali; 8, Kynraidakh; 9, Zyryanka

Andrei-Tas block is locally destructed along the fault line.

Also visible in the epicentral area of the Ilin-Tas earthquake is a system of seismotectonic deformations and seismogravitational manifestations (Fig. 3(B)). In the upper reaches of the Nikondya River and its tributary, the Buor-Yuryakh River, one can clearly see rejuvenation of the EW-striking plane of a reverse fault with a strike-slip component identified from the geological survey data. On the eastern side of the fault, which directly adjoins the epicentral zone of the Ilin-Tas event, a series of radial fractures and numerous seismogravitational manifestations are clearly visible. In the upper course of the Chalkin River, a 6-km-long NE-striking fault is identified, which transects the divide between the tributaries of the Selennyakh and Indigirka Rivers. Numerous slumps and slides are noted here along the perimeter of contacting Paleogene-Neogene and Cretaceous rocks.

The described seismotectonic and seismogravitational manifestations were likely produced by a series of seismic events that occurred within the Andrei-Tas block $\left(1999, \mathrm{M}_{\mathrm{s}}=5.1 ; 2008, \mathrm{M}_{\mathrm{s}}=6.1\right.$; $\left.2013, \mathrm{M}_{\mathrm{s}}=6.9\right)$ and by earlier paleoearthquakes. This is evidenced by spatial coincidence of the areas of 


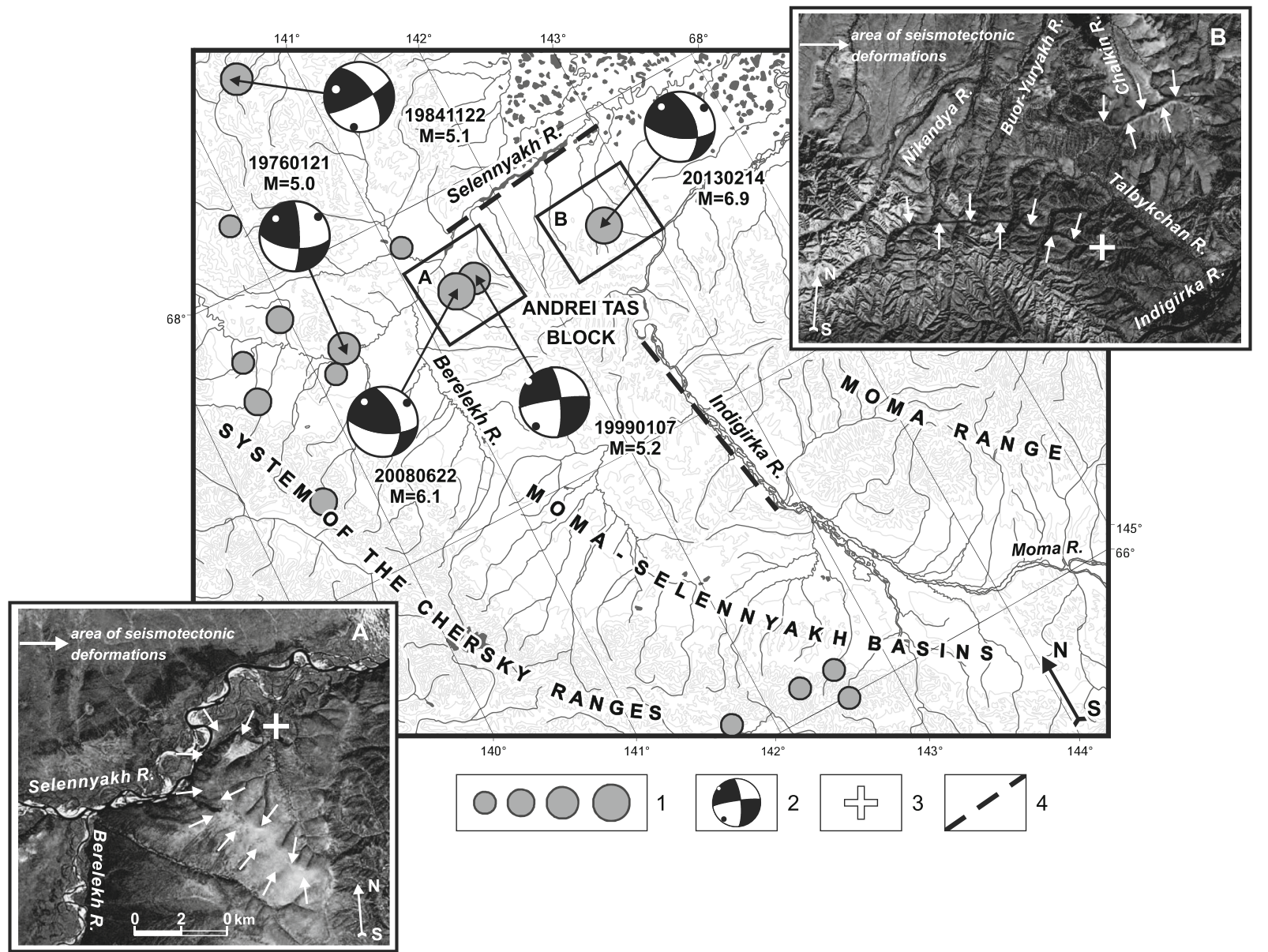

Fig. 3 Strong earthquakes on the northeastern side of the MomaSelennyakh basins within the limits of the Andrei-Tas seismic maximum [after Imaeva et al. (2011)], supplemented. 1, Epicenters of earthquakes with magnitude $\mathrm{M}_{\mathrm{s}}$ (Richter scale): 3.0-3.9, 4.0$4.9,5.0-5.9,6.0-6.9 ; 2$, focal mechanism stereograms with the

seismotectonic deformations and the innermost isoseism zones of the mentioned seismic events. The morphology of the Earth's crust dislocations agrees well with the type of motions determined from the focal mechanism solutions of the earthquakes.

\section{Active faults and cenozoic dislocations}

Analysis of the kinematics of active faults and deformations established in Cenozoic rocks on the northeastern side of the Yana-Indigirka segment showed that they are mainly thrusts, reverse faults with a strike-slip component, and strike slips (Imaev et al. 1990; Imaeva et al. 2010, 2012). The epicentral zone of the Ilin-Tas earthquake is confined to the northwestern side of the area of date and magnitude of earthquakes; 3, on inset maps: $A$ (space image on the lower left), epicenter of the Yune 22, 2008, AndreiTas earthquake; $B$ (space image on the top right), epicenter of the Feb 14, 2013, Ilin-Tas earthquake. Arrows show the location of surface deformations; 4 , straightened segments of rivers

dynamic influence of the fault under the same name, which forms part of the regional strike-slip system of the Verkhoyansk-Kolyma folded region (Fig. 1). The IlinTas fault is traced along the boundary of the Ilin-Tas folded zone and the Indigirka-Zyryanka basin up to the Indigirka River (Fig. 4). The available structural-geological data indicate that it is a reverse fault with a leftlateral strike-slip component (Gusev 1979; Imaev et al. 2000). In the fault zone, changes in the magnetic anomaly patterns are observed, and in the central part of the Andrei-Tas block, a gravity field maximum with a sharp gravitational step is noted (Suvorov and Kornilova 1986; Fujita et al. 2009). In the upper reaches of the Myatis' and Badyarikha Rivers, the Ilin-Tas fault is traced as a 300-400-m-thick zone of brecciation adjoined by low-amplitude thrusts at an acute angle. In 
the middle course of the Indigirka River, the fault is expressed as a 2-km-wide cleavage zone with a fault plane dipping at $60^{\circ}$ to the southwest. It forms here fanlike systems of reverse faults and thrusts with associating folds of Cenozoic deposits of the IndigirkaZyryanka basin (Gusev 1979; Imaev et al. 1990, 2000).

On the 1:500,000 geologic map, the epicentral zone of the Ilin-Tas earthquake is confined to a series of reactivated EW- and NW-striking faults developed at the boundary between the Upper Jurassic schists and mudstones, which compose the arch-block structure of the Ilin-Tas folded zone, and the Cretaceous-PaleogeneNeogene sandy-clayey deposits of the Indigirka-
Zyryanka basin (Fig. 4). The main shock and aftershocks are localized in a duplex structure that resulted from reverse faulting with a strike-slip component in the focus of the 2013 Ilin-Tas earthquake. The echelon-like reverse faults gravitate to the northwestern termination of the Ilin-Tas fault. A structural-dynamic model of the epicentral zone of the Ilin-Tas earthquake is shown in the inset of Fig. 4.

Detailed structural-geological studies of deformations in the zones of the above-mentioned reverse faults with a strike-slip component show that they are characterized by a southwestern virgation of the fault planes. The hanging walls of the faults are overthrust onto the

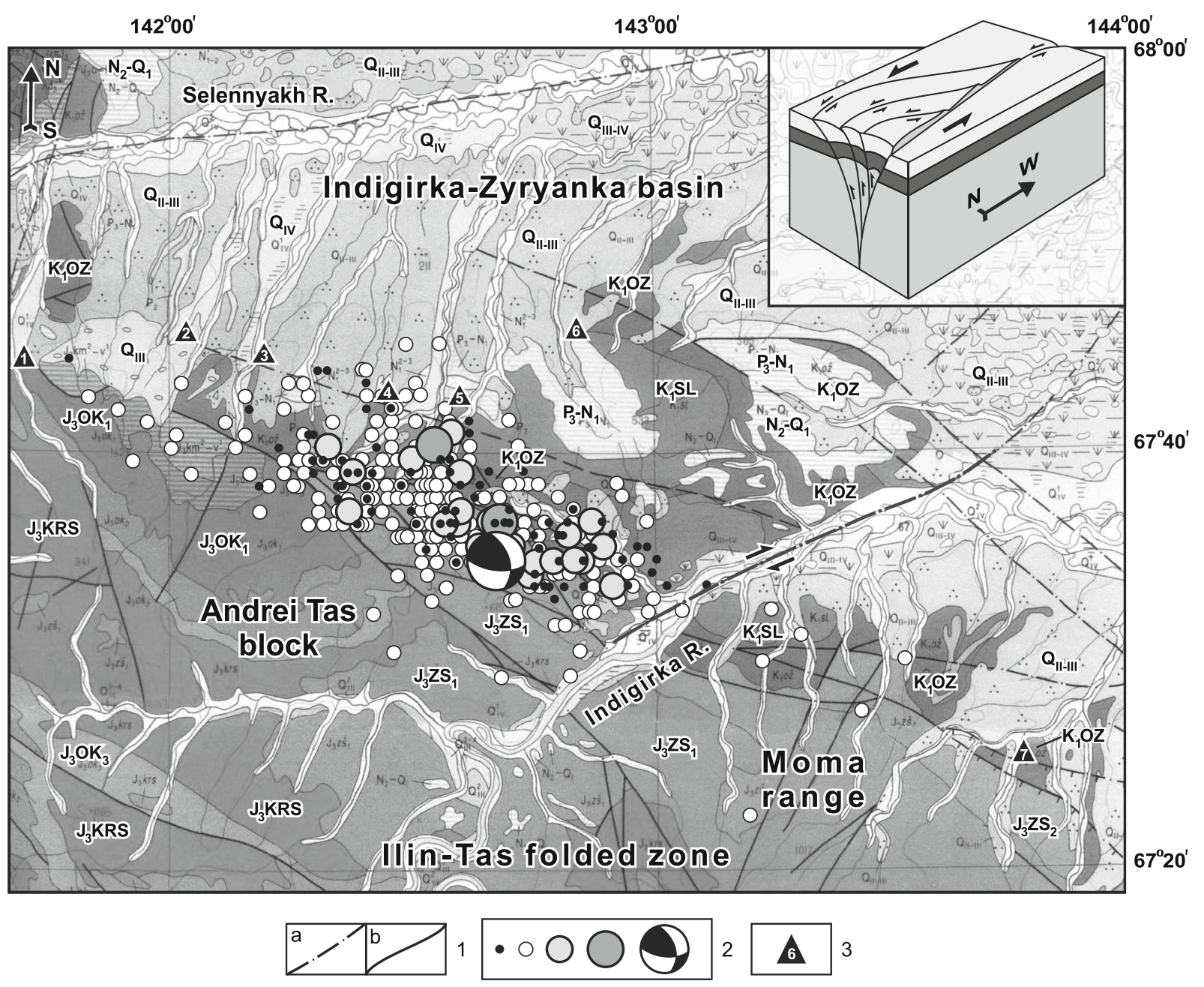

Fig. 4 Map of aftershocks and structural dynamic model of the Ilin-Tas (Abyi) earthquake. 1, Zone of the northwestern end of the Ilin-Tas fault established from the data of geological survey at a scale of 1:500,000: $a$ assumed (dashed), $b$ defined (solid); 2, epicenters of aftershocks with magnitude $\mathrm{mb}$, respectively: $\leq 2.0$, 2.1-3.4, 3.5-4.5, 4.6-5.4, 5.5-6.9 (focal mechanism of the Ilin-
Tas earthquake); 3, exposures of Cenozoic sections (numbers in triangles: 1, Sorochkolakh; 2, Tomtor; 3, Sisiktyakh; 4, Bolchug; 5, Nikondya; 6, Chalkin; 7, Kyllakh. Shown in the index is the structural dynamic model of the event [after Moores and Twiss (1995)] 
footwalls. As a result, the Upper Jurassic deposits of the Bastakh Formation overlap, with an amplitude from a few hundred meters to a few kilometers, the Cretaceous, Neogene, and even Quaternary rocks both in the piedmont and within the Indigirka-Zyryanka basin (Imaev et al. 1990, 2000). A geologic cross-section on the Kyllakh River (right tributary of the Indigirka River in its middle course) most fully characterizes compressive conditions in the area and the related reverse faults and thrusts (Fig. 4, N7; Fig. 5). Here, the Oligocene, Miocene, and Pliocene rocks are draped into packets of folds with dip angles of $75-80^{\circ}$. On the southwest, the folds are cut by a thrust fault on which the Lower Cretaceous rocks of the Ozhogina Formation are overthrust onto the Tertiary strata. As seen from the left part of Fig. 5, the Lower Cretaceous sandstone unit (A) unconformably overlies the sandy-clayey unit of the same age (B) along the thrust. The units have different dip angles $\left(\mathrm{A}, 45^{\circ} ; \mathrm{B}, 25-30^{\circ}\right)$, while their dip azimuth is the same $\left(220^{\circ}\right)$. Thus, the whole of the Lower Cretaceous rock sequence is overthrust onto the Oligocene (?) clayey unit wherein fragments of a fold with steep $\left(65-70^{\circ}\right)$ dip angles are well traced.
Further north, the Cenozoic rocks are intensely dislocated by numerous small ruptures subparallel to the main thrust (dip azimuth $220^{\circ}$, dip angle $30^{\circ}$ ). The ruptures are well traced by clay and coal interbeds in the eastern more sandy part of the section. Analysis of fracturing showed some displacement in the location of fractures in the Lower Cretaceous and Cenozoic rocks. In the Lower Cretaceous rocks, the axis of compression is found to be directed to the east as opposed to the northeasterly direction (azimuth $20-30^{\circ}$ ) determined for the Cenozoic rocks. This may be explained by that the motion of the Lower Cretaceous nappe was controlled by the global tectonic stress field in contrast to the motion of the Cenozoic nappe, which was related to the regional stress field (Imaev et al. 2000).

Numerous fracture systems established in all natural exposures and sections in the frontal part of the Indigirka-Zyryanka basin originated at the time of intense folding. Under the present-day compression, these fractures serve as planes on which horizontal motion occurs. This causes displacement of the existing fold structures. More common at the exposures are through fractures forming a single fracture system displacing the bedding.

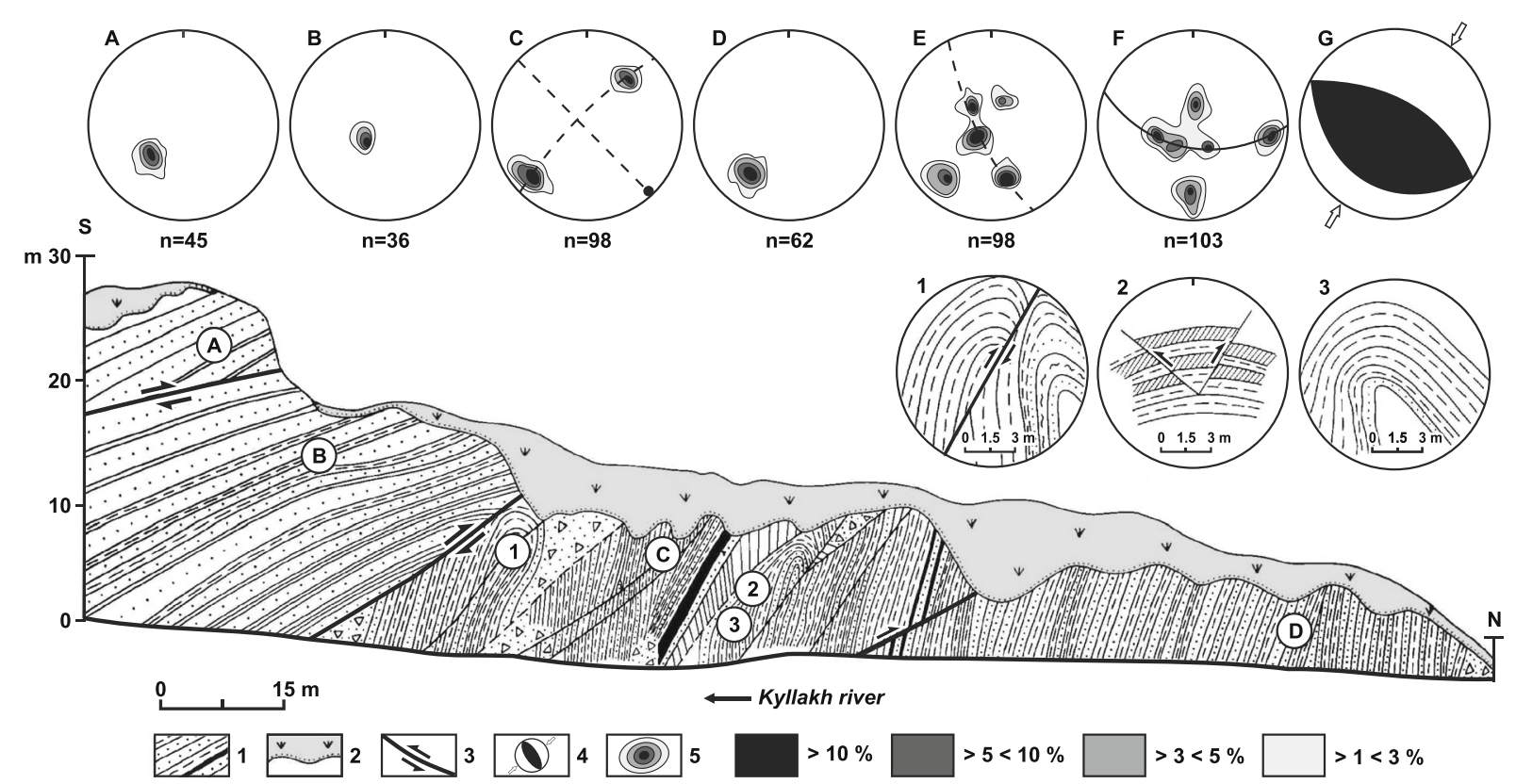

Fig. 5 Typical deformations of the Lower Cretaceous and Cenozoic (Oligocene-Miocene) rocks in the frontal part of the Indigirka-Zyryanka basin (Kyllakh River) [after Imaev et al. (1990, 2000)]. 1, Alternating sandstone, clay, and coal; 2, turfcovered parts of exposures; 3 , reconstructed position of the areas of compression (white color) and extension (black color) from structural-geological mapping data; 4 , density isolines of structural elements: bedding in the Lower Cretaceous ( $A$, Ozhogina Formation; $B$, Buorkemyus Formation) and Paleogene-Neogene $(C$, $D$ Kyllakh and Myatis Formations) rocks; fracturing in the Lower Cretaceous $(E)$ and Cenozoic $(H)$ rocks; $I$, reconstructed tectonic stress field; $1-3$, larger-sized fragments of exposures 

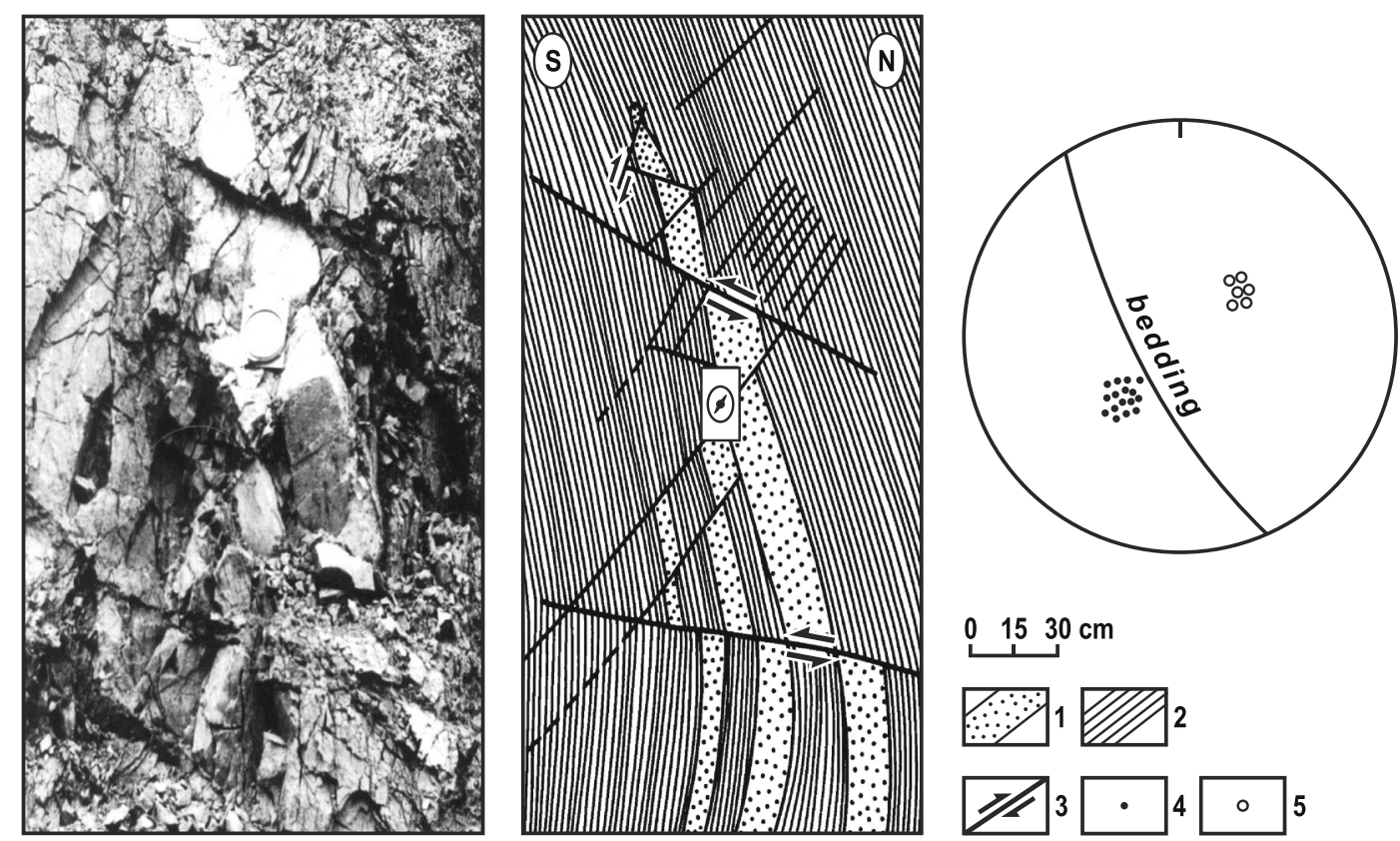

Fig. 6 Low-amplitude faults in Miocene strata on the Elgandya River. 1, Sandstone; 2, clays; 3, thrusts and reverse faults; 4, poles of lowamplitude thrusts; 5 , poles of measured fractures conjugate with thrusts

They are locally accompanied by less numerous fractures of smaller size whose kinematics can be easily determined from the displacement of bedding, quartz veins, etc. The amplitude of displacement normally varies from 1-2 $\mathrm{m}$ to a few centimeters (Fig. 6). The prevailing thrust-type motion along these small fractures is well supported by the nature of striation on slickensides.

A wide range of fold deformations (Fig. 4, N1-6) is also recognized in the innermost isoseism zone of the Ilin-Tas earthquake where Cenozoic rocks of the IndigirkaZyryanka basin are dislocated, at the boundary with the Andrei-Tas block, into folds and ruptures (Imaev et al. 1990, 2000). Specifically, the Eocene deposits of the Tomtor Formation on the Tomtor River (Fig. 4, N2) form a monocline gently $\left(15-25^{\circ}\right)$ dipping to the northeast (dip azimuth $40-45^{\circ}$ ). Tectonic fractures in natural exposures on the Tomtor River mostly have low dip angles (35-45 ) except for the system of rare fractures dipping to the east at $55-60^{\circ}$. Similar dip angles are characteristic of sedimentary rock units of the Oligocene Bolchug Formation, which are exposed at the mouth of the Bolchug River, a left tributary of the Nikondya River (Fig. 4, N4).

In the River basin of Sisiktyakh (Fig. 4, N3), the Eocene rocks are deformed into folds with steep (75$80^{\circ}$ ) dip angles. A general dip of the sequence is toward northeast (dip azimuth $35-55^{\circ}$ ). Also present are small folds with horizontal hinges (strike azimuth $330^{\circ}$ ) indicating that the rocks underwent additional SW-NE compression on the side of the Andrei-Tas block. The Upper Miocene rocks of the Nikondya Formation are also dislocated by thrusts. The dislocations are well established from the unconformable contact of two different lithological units observed in the middle course of the Nikondya River (Fig. 4, N5). The northern part of the Nikondya section is represented by a SW-striking clay rock unit with alternating coal and siltstone interbeds (dip azimuth $250^{\circ}$, dip angle $35-40^{\circ}$ ). The eastern (allochthonous) part of the section is composed exclusively of clay rocks and has different dip azimuth $\left(190^{\circ}\right)$ and dip angle $\left(25^{\circ}\right)$. The fault plane is traced by numerous slickensides mainly developed in the Cenozoic allochthonous nappe (Imaev et al. 1990, 2000).

\section{Seismicity}

Several seismic maximums (maxima A-D in Fig. 1) have been established in the Yana-Indigirka segment of the Chersky seismotectonic zone forming a continental part of the Arctic-Asian seismic belt. The most intense is the seismic maximum of the Andrei-Tas block where, along with numerous weak shakes, strong earthquakes such as the 1984 Uyandina event (intensity VII, $\mathrm{M}_{\mathrm{s}}=5.6$ ), the 1999 event (intensity VI-VII, $\mathrm{M}_{\mathrm{s}}=5.1$ ), 
and the 2008 Andrei-Tas event (intensity VIII, $\mathrm{M}_{\mathrm{s}}=6.1$ ) have been recorded earlier (Figs. 1 and 3). According to data obtained by the Geological Survey of the Russian Academy of Sciences (http://www.ceme.gsras.ru), the Ilin-Tas (Abyi) earthquake with $\mathrm{M}_{\mathrm{s}}=6.9$ occurred on Feb 14, 2013. The epicenter (coordinates $67.58^{\circ} \mathrm{N}$ and $142.67^{\circ} \mathrm{E}$ ) was located in the northwestern arm of the Moma Range, at the boundary with the IndigirkaZyryanka basin, in an unpopulated mountain-taiga area. It occurred at $13^{\mathrm{h}} 13^{\mathrm{m}} 51.6^{\mathrm{s}}$ p.m. Greenwich mean time (about midnight local time).

In spite of the night time, most of the population felt the shake. People from 22 settlements in the interfluve of the Yana, Indigirka, and Kolyma Rivers were asked to tell what they had seen and felt. Shakes of intensity II and III were detected at a distance as large as $400 \mathrm{~km}$ from the epicenter (Kuyga, Chokurdakh, Kazachye, and other villages). From eyewitness accounts by telephone, news from mass media, post communications, etc., an isoseism map is constructed showing the distribution of seismic shakes at the Earth's surface (Koz'min et al. 2013). Areas with intensities VII, VI, V, and IV on the MedvedevSponhoeuer-Karnik (MSK)-64 scale are outlined. The overall territory covered by the event is more than $500,000 \mathrm{~km}^{2}$. The focal depth is $14 \mathrm{~km}$, the magnitude $\left(\mathrm{M}_{\mathrm{s}}\right)=6.9$, and the epicentral intensity reaches IX. It should be noted that if the seismic event had occurred in summer time, during seasonal thawing of ground, the intensity would have been one unit higher at a minimum.

It was found that isoseism ellipses were elongated in the direction from NE to SW across the strike of tectonic structures developed in the Chersky seismotectonic zone (Fig. 7). In the Yana-Indigirka segment, a similar strike of isoseisms (Fig. 8) was observed during the 1984 Uyandina and the 2008 Andrei-Tas earthquakes (Imaeva et al. 2009, 2011). Isoseism maps were earlier constructed for many earthquakes that occurred within the Chersky seismotectonic zone (Imaev et al. 1990, 2000; Koz'min et al. 2001). There is a tendency observed here: all isoseisms have a form of ellipses with a major axis elongated in NW direction along the strike of major seismically active faults. An exception is provided by earthquakes within the seismic maximum of the Andrei-Tas block (Imaeva et al. 2011).

After the main shock, during the latter half of Feb and in Mar 2013, seismic networks of the Yakut Division of the Geophysical Survey, Siberian Branch, Russian Academy of Sciences, and the Michigan State University (USA) registered over 3000 aftershocks (Koz'min et al. 2013), among them 20 with a magnitude $\left(\mathrm{m}_{\mathrm{b}}\right)$ of 4.4-5.2 and epicentral intensity of V-VII (Table 1). The epicenters of aftershocks form a band up to $40 \mathrm{~km}$ wide and $120 \mathrm{~km}$ long, extending along the NW termination of the Ilin-Tas fault (Fig. 4). Within the Andrei-Tas block, the aftershocks were registered in the divide between the Indigirka River and its left tributary Selennyakh River, as well as on the right bank of the Indigirka River. The spatial orientation of the aftershock area coincides with the strike of the Ilin-Tas fault (azimuth $310^{\circ}$ ).

Comparison of the geological characteristics of the Ilin-Tas thrust with the focal mechanism parameters of the Ilin-Tas earthquake determined by the centroid moment tensor method (Table 2) shows that they agree well. The NPI plane of NW strike (azimuth $324^{\circ}$ ) dipping to SW at an angle of $43^{\circ}$ may be taken as a working plane of the rupture in the focus. The compression strain (P) oriented at an angle of $3^{\circ}$ to the horizon was directed from NE to SW. This is consistent with the thrust-type motion in the earthquake focus.

\section{Dynamics of seismogenerating structures}

Isoseisms of earthquakes in the Andrei-Tas block are oriented across the fault lines in contrast to isoseisms elongated along the fault lines in other parts of the Chersky seismotectonic zone. This may be explained by the maximum pressure exerted by the Kolyma-Omolon superterrane on the Eurasian plate (Figs. 1, 7, and 8) in this place. Here, in the zone of contact of the Eurasian and North American plates, favorable conditions were created for accumulation of tectonic strains, which led to reactivation of seismotectonic processes. The Kolyma-Omolon terrane acts as an indentor. The general sense of its motion coincides with the spatial orientation of isoseisms extending from NE to SW (azimuth 50-85 ).

The pressure exerted on the Eurasian plate by the North American plate in the northeast resulted in the formation, in front of the indentor, of northwestern left-lateral and northeastern right-lateral strike slips and the development at their ends of reverse faults and thrusts (Fig. 1). Notably, simultaneous formation of right- and left-lateral strike slips on either side of the indentor is typical for many collisional zones. An example is provided by the well-studied structures in the Alpian-Himalayan belt resulted from horizontal (lateral) squeezing out of rock masses (Kopp 1997; Leonov et al. 2009; Trifonov et al. 2002). It is noted that at the sites of collision of lithospheric plates which 


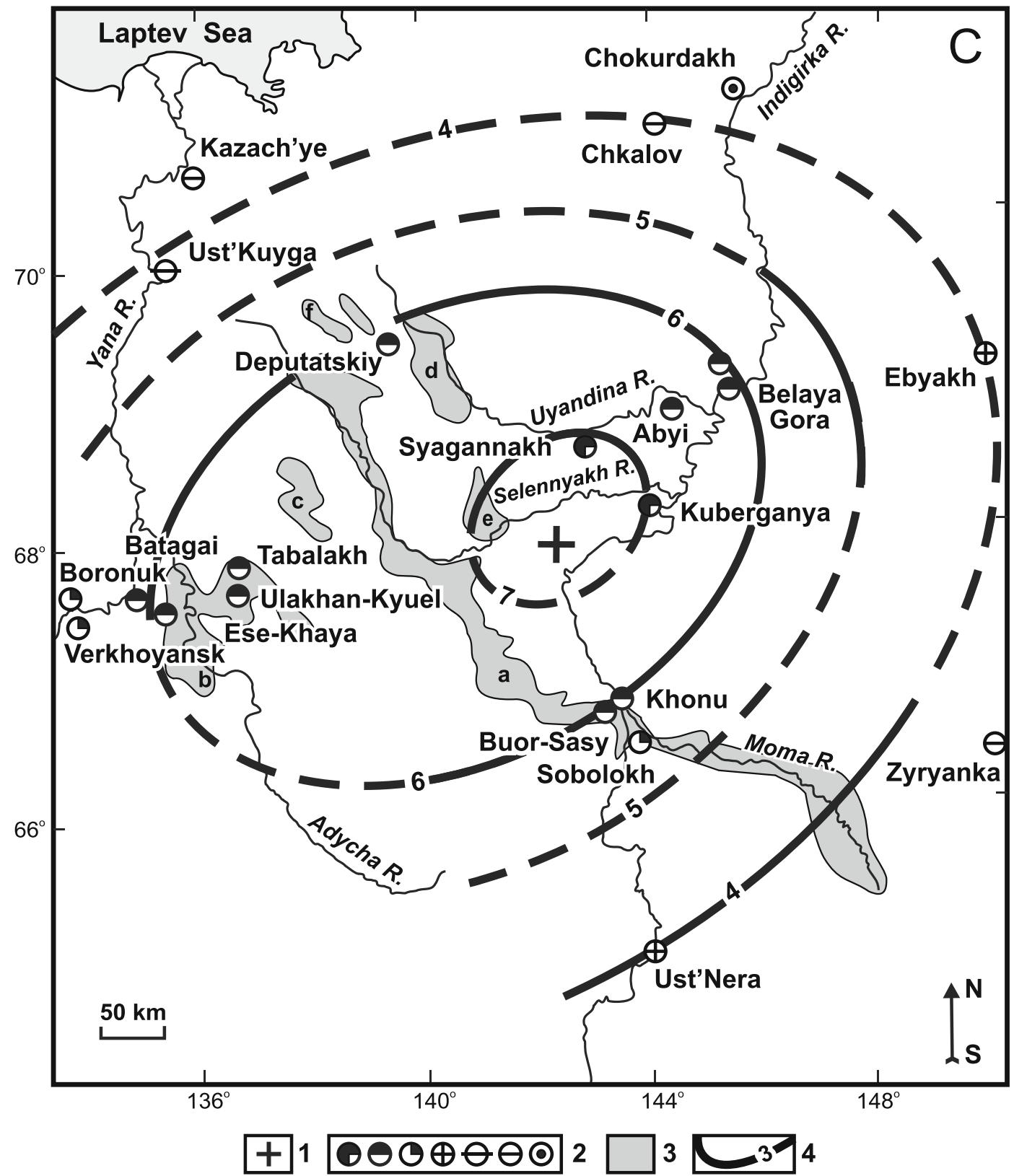

Fig. 7 Isoseisms of the Ilin-Tas (Abyi) earthquake. 1, Epicenter of the main shock from instrumental data; 2, intensity (scale MSK64), respectively: 7, 6, 5, 4, 3-4, 3, and 2; 3, Cenozoic basins: $a$

experience horizontal compression, the material is squeezed out laterally along the orogenic belt into places of lesser compression. Piling up of the squeezed out crustal rock masses leads to the formation of swells in the orogenic belts and of transverse fold zones.

A similar situation is observed in the Yana-Indigirka segment of the Chersky seismotectonic zone, in the area between the Yana and Indigirka Rivers (Fig. 1). In the
Moma-Selennyakh, $b$ Tuostakh, $c$ Nenneli, $d$ Uyandina, $e$ Tommot, $f$ Irgichan; 4 , isoseisms: solid line drawn with confidence, dashed line drawn without confidence

middle course of the Indigirka River, clustering of faults is evident, which to the north and southeast branch out to deform a greater part of the Yana-Indigirka segment. As a result, the segment is faulted into miniblocks which move northward and northwestward in the direction of the Polousny and Kular Ranges. The contact of the blocks with the EW-striking structures of the Polousny Range causes right-lateral and left-lateral strike slip 
Fig. 8 Isoseism of elippses of the Uyandina (a) and Arga-Tas (b) earthquakes. 1, Epicenter of the earthquake from instrumental data; 2, intensity (scale MSK-64), respectively: $6-7,6,5-6,4-5,3-$ 4, 4, 3-4, 3, 2-3, 2, and not felt; 3, Cenozoic basins: $a$ Moma-

Selennyakh, $b$ Tuostakh, $c$

Nenneli, $d$ Uyandina, $e$ Tommot, $f$ Irgichan; 4, isoseisms: solid line drawn with confidence, dashed line drawn without confidence
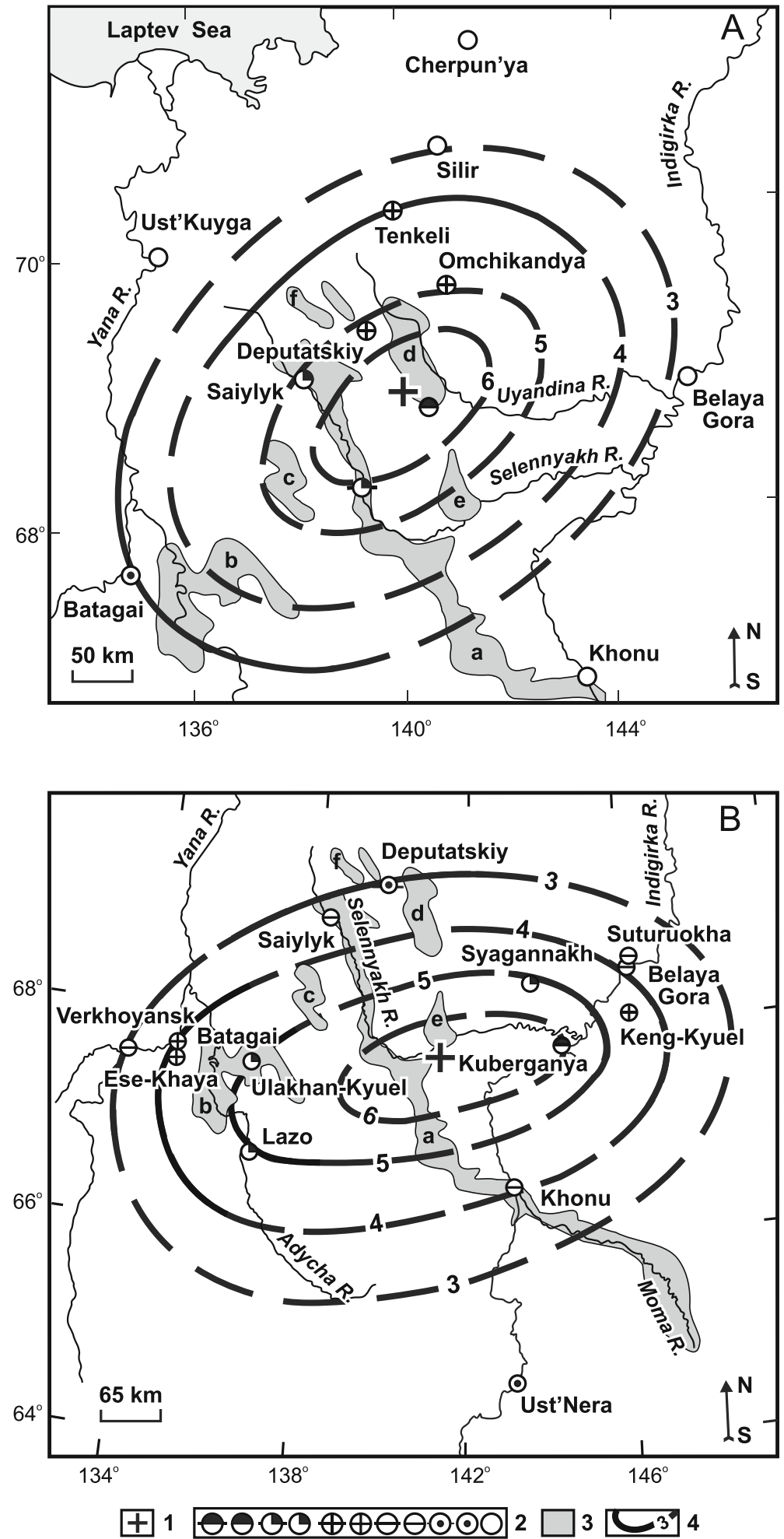

motions along the block boundaries and is indicative of squeezing out of the material.

The mentioned peculiarities of modern geodynamics of the Chersky seismotectonic zone are reflected in the 
Table 1 Epicentral parameters of the Ilin-Tas (Abyi) earthquake and its large aftershocks with $\mathrm{m}_{\mathrm{b}} \geq 4.4$, Feb 14, 2013 (http://www.ceme.gsras.ru)
Date and origin time given in GMT. Latitude in degrees north, longitude in degrees east. Magnitude is $\mathrm{mb}$

\begin{tabular}{llllll}
\hline Date & Origin (h:min:s) & Latitude & Longitude & $\begin{array}{l}\text { Depth } \\
(\mathrm{km})\end{array}$ & Magnitude $\left(\mathrm{m}_{\mathrm{b}}\right)$ \\
\hline Feb 14 & $13: 13: 51$ & 67.58 & 142.67 & 12 & 6.8 \\
Feb 14 & $13: 18: 37$ & 67.61 & 142.68 & 10 & 5.2 \\
Feb 14 & $13: 28: 05$ & 67.60 & 141.96 & 10 & 4.9 \\
Feb 14 & $13: 44: 29$ & 67.81 & 142.60 & 10 & 4.9 \\
Feb 14 & $13: 47: 15$ & 67.58 & 142.74 & 10 & 4.8 \\
Feb 14 & $13: 52: 15$ & 67.65 & 142.38 & 10 & 4.6 \\
Feb 14 & $15: 08: 34$ & 67.69 & 142.58 & 10 & 5.1 \\
Feb 14 & $15: 14: 55$ & 67.85 & 142.53 & 10 & 5.0 \\
Feb 14 & $16: 10: 57$ & 67.79 & 142.78 & 10 & 4.4 \\
Feb 14 & $17: 17: 40$ & 67.58 & 142.34 & 10 & 4.8 \\
Feb 14 & $20: 26: 13$ & 67.63 & 142.74 & 10 & 4.9 \\
Feb 15 & $06: 23: 00$ & 67.61 & 142.75 & 10 & 4.6 \\
Feb 15 & $12: 39: 53$ & 67.68 & 142.52 & 10 & 4.8 \\
Feb 15 & $16: 32: 55$ & 67.66 & 142.19 & 10 & 5.0 \\
Feb 16 & $02: 01: 14$ & 67.48 & 142.57 & 10 & 4.9 \\
Feb 22 & $09: 31: 54$ & 67.70 & 142.93 & 15 & 4.9 \\
Feb 22 & $23: 31: 59$ & 67.60 & 142.53 & 15 & 4.8 \\
Feb 27 & $18: 23: 34$ & 67.56 & 142.76 & 15 & 4.6 \\
Feb 28 & $00: 33: 14$ & 67.60 & 142.44 & 15 & 4.8 \\
\hline & & & & &
\end{tabular}

structure of epicentral zones of local earthquakes. A seismic maximum is observed in the area experiencing the greatest pressure on the side of the Kolyma-Omolon terrane (indentor), which is expressed as the Andrei-Tas cluster of earthquake epicenters (Figs. 1 and 3). Similar clusters of the earthquake foci are observed on either side of the Andrei-Tas maximum, at the flanks of the Chersky zone (Polousny Range maximum in the north).
The revealed seismotectonic setting in the region indicates that active tectonic structures of the Chersky Range are developing under conditions of transpression (compression with a strike slip) promoted by the collision of the Eurasian and North American plates moving toward each other at different rates (Imaev et al. 1990, 2000; Imaeva et al. 2009, 2010, 2011; Fujita et al. 2009). Most seismically potential is the Andrei-Tas block,

Table 2 Focal mechanism parameters of the Feb 14, 2013, Ilin-Tas (Abyi) earthquake with $\mathrm{M}_{\mathrm{s}} 6.9$ (main shock)

\begin{tabular}{|c|c|c|c|c|c|c|c|c|c|c|c|c|c|c|c|c|}
\hline \multirow{3}{*}{$\begin{array}{l}\text { Origin } \\
\text { (h:min:s) }\end{array}$} & \multirow{3}{*}{$\begin{array}{l}\text { Depth } \\
(\mathrm{km})\end{array}$} & \multicolumn{2}{|c|}{ Mag } & \multicolumn{6}{|c|}{ Principal axes } & \multicolumn{6}{|c|}{ Nodal planes } & \multirow[t]{3}{*}{ References } \\
\hline & & \multirow[t]{2}{*}{$\mathrm{M}_{\mathrm{s}}$} & \multirow[t]{2}{*}{$M_{\mathrm{w}}$} & \multicolumn{2}{|l|}{$\mathrm{T}$} & \multicolumn{2}{|l|}{$\mathrm{N}$} & \multicolumn{2}{|l|}{$\mathrm{P}$} & \multicolumn{3}{|l|}{ NP1 } & \multicolumn{3}{|l|}{ NP2 } & \\
\hline & & & & PL & $\mathrm{AZM}$ & PL & AZM & PL & AZM & STK & DP & SLIP & STK & DP & SLIP & \\
\hline $13: 13: 51.6$ & 14 & 6.9 & 6.9 & 61 & 323 & 29 & 143 & 0 & 53 & 117 & 52 & 52 & 349 & 52 & 128 & $\begin{array}{l}\text { ftp.gsras.ru/pub/ } \\
\text { Teleseismic_bulletin/2013 }\end{array}$ \\
\hline $13: 13: 59.4$ & 12 & 6.7 & 6.7 & 76 & 324 & 13 & 129 & 3 & 220 & 324 & 43 & 109 & 118 & 50 & 73 & $\begin{array}{l}\text { http://www.globalcmt.org/ } \\
\text { CMTsearch.html }\end{array}$ \\
\hline
\end{tabular}

Origin time given in GMT. Magnitude is ISC $\mathrm{M}_{\mathrm{s}}$ and $M_{\mathrm{w}}$. Axis is given by plunge and azimuth. Nodal planes are given by strike, dip, and slip $T$ tension, $N$ normal, $P$ pressing 
which experiences the greatest pressure on the side of the Kolyma-Omolon terrane located in the frontal part of the North American plate. The NE-SW motion of the superterrane (azimuth 50-85 $5^{\circ}$ coincides with the orientation of the major axis of the isoseism ellipses constructed from observations of macroseismic effects of the Uyandina, Andrei-Tas, and Ilin-Tas earthquakes (Imaeva et al. 2011).

Open Access This article is distributed under the terms of the Creative Commons Attribution License which permits any use, distribution, and reproduction in any medium, provided the original author(s) and the source are credited.

\section{References}

Fujita K, Kozmin BM, Mackey KG et al (2009) Seismotectonics of the Chersky seismic belt, eastern (Yakutia) and Magadan district, Russia In: Geology, geophysics and tectonics of Northeastern Russia: a tribute to Leonid Parfenov. Stephan Mueller Spec. Publ. (Ser., 4):117-145

Gaiduk VV, Prokopiev AV (1999) Methods of studying fold-andthrust belts. Nauka, Novosibirsk, 160 pp. (in Russian)

Gusev GS (1979) Fold structures and faults of the VerkhoyanskKolyma system of Mesozoides. M.:, Nauka, 207 pp. (in Russian)

Imaev VS, Imaeva LP, Koz'min BM (1990) Active faults and seismotectonics of northeast Yakutia. Yakutian Science Center, Yakutsk, 138 pp. (in Russian)

Imaev VS, Imaeva LP, Koz'min BM (2000) Seismotectonics of Yakutia. GEOS Moscow, 226 p. (in Russian)

Imaeva LP, Koz'min BM, Imaev VS (2009) Seismotectonics of the northeastern segment of the Chersky Range zone. Otechestvennaya Geol N5:94-100 (in Russian)

Imaeva LP, Imaev VS, Koz'min BM (2010) Seismotectonic analysis of the Yana-Indigirka segment of the Chersky zone. Phys Earth N12:79-86 (in Russian)

Imaeva LP, Koz'min BM, Imaev VS (2011) Dynamics of the focal zones of strong earthquakes on the northeastern flank of the Moma-Selennyakh basins. Otechestvennaya Geol N5:113119 (in Russian)

Imaeva LP, Imaev VS, Koz'min BM, Smekalin OP (2012) Regularities of seismotectonic destruction of the Chersky seismic belt (ChSB) // Materials of the All-Russian Conference "Contemporary geodynamics of Central Asia and hazardous natural processes: results of investigation on a qualitative basis". Irkutsk: IZK SO RAN (V.2), Irkutsk:28-31 (in Russian)
Kopp ML (1997) Lateral squeezing-out structures in the Alpian-Himalayan collisional belt. Nauchny mir, Moscow, 313 pp. (in Russian)

Koz'min BM, Imaev VS, Imaeva LP (2001) Seismicity and contemporary geodynamics In: Tectonics, geodynamics and metallogeny of the Sakha Republic (Yakutia) territory., MAIK “Nauka”,Moscow, 33-67 (in Russian)

Koz'min BM, Shibaev SV, Imaeva LP, Imaev VS, Petrov AF, Timirshin KV (2013) Present-day activity of seismic belts of Yakutia In: continental rifting and accompanying processes. Materials of the $2 \mathrm{~d}$ all-Russian symposium with international participants. IZK SO RAN, Irkutsk, 167-171 (in Russian)

Leonov MG, Kolodyazhny S, Yu, Zykov DS (2009) Within-plate structural-kinematic parageneses as indicators of lateral flows in the lithosphere of mobile belts and platforms In: Geodynamic evolution of the lithosphere of the Central Asian mobile belt (from ocean continentward). V.1. Irkutsk, p 170-173 (in Russian)

Moores EM, Twiss RJ (1995) Tectonics. W.H.Freeman and Company, New York, 415 pp

Parfenov LM (1984) Continental margins and island arcs of Mesozoides in northeast Asia. Nauka, Novosibirsk, 191 pp (in Russian)

Parfenov LM et al (2001) A collage of terranes in the Verkhoyansk-Kolyma orogenic region In: Tectonics, geodynamics and metallogeny of the Sakha Republic (Yakutia) territory., MAIK "Nauka", Moscow, 199-254 (in Russian)

Prokopiev AV, Deikunenko AV (2001) Deformation structures of fold-and-thrust belts In: Tectonics, geodynamics and metallogeny of the Sakha Republic (Yakutia) territory, MAIK, Moscow. pp 156-198 (in Russian)

Shebalin NV, Ulomov VI, Tatevossian RE, Trifonov VG, Yoffe AI, Kozhurin AI (1995) Unified seismogeological taxonomv of the Northern Eurasia. In: International Union Geology and Geophysics conference, Abstract, SB21C-14. Boulder. U.S.A

Suvorov VD, Kornilova ZA (1986) Thickness of the Earth's crust in the southeastern Verkhoyansk-Kolyma region. Tikhookeanskaya Geol N4:32-35 (in Russian)

Trifonov VG, Soboleva OV, Trifonov RV, Vostrikov GA (2002) Contemporary geodynamics of the Alpian-Himalayan collisional belt. Transactions of GIN RAN. Issue 541. GEOS. Moscow, 225 pp. (in Russian)

Ulomov VI (1995) On basic principals and technical recommendations in constructing a new seismic zonation map for the Russian Federation territory In: Seismicity and seismic zonation of northern Eurasia. Issue 2-3. M.: OIFZ RAN, Moscow: 9-26 (in Russian)

Ulomov VI, Shumilina LS (1998) A set of new general seismic zonation maps for the Russian Federation territory. Antiseismic Constructions N4, pp. 30-34 (in Russian) 